\title{
Volitelova sebedeterminace v kompatibilistické verzi
}

\author{
David Peroutka \\ Filozofická fakulta \\ Univerzita Jana Evangelisty Purkyně \\ Pasteurova 13, 40096 Ústí nad Labem \\ peroutka.ujep@seznam.cz
}

V reakci na knihu Petra Dvořáka Kauzalita činitele. Úvod do analytické diskuse o svobodě vưle hájím určitý typ kompatibilismu. Dvořák upozorňuje, že pokud bylo něčí rozhodnutí predeterminováno od něj odlišnými příčinami, pak onomu jedinci za jeho volbu nepřisuzujeme morální odpovědnost. Mým návrhem je však „asymetrické“ řešení otázky. V oblasti predeterminovaných voleb připouštím nepř́tomnost odpovědnosti $\mathrm{v}$ př́padě všech morálně zlých voleb, nikoli však v případě všech voleb hodnocených jako morálně dobré. Existují totiž takové dobrovolné volby, při kterých sice nejsme s to - napřr. na základě silných morálních důvodů - volit jinak, avšak přesto vnímáme své rozhodnutí jako svobodné. Navíc platí, že $i$ kdybychom se při tom dověděli, či uvěřili, že daná volní nutnost není důsledkem naší minulé „libertariánské“ sebeformace, stěží by nám takové mínění zabránilo cítit se ve své volbě svobodnými. Způsoby, jakými svobodu vůle prožíváme, bychom ovšem měli jakožto filosofové respektovat.

Klíčová slova: svoboda vůle, sebedeterminace, volní nutnost, kompatibilismus, libertarianismus, Petr Dvořák

\section{1. Úvod}

Kniha Petra Dvořáka Kauzalita činitele ${ }^{1}$ je více než jen Úvodem do analytické diskuse o svobodě vůle (jak zní podtitul). Představuje určité konkrétní řešení diskutovaného problému. Autor odmítá tzv. standardní teorii, kořenící ve filosofii Davida Humea a rozvinutou zejména

1 Dvořák (2020). 
Donaldem Davidsonem, podle které je volba s nutností generována určitými mentálními či psychologickými stavy, totiž našimi míněními (beliefs) a tužbami (desires). Dvořák proti tomuto stanovisku obhajuje (v návaznosti na Thomase Pinka a další autory) teorii, podle které volbu, resp. intenci (záměr) nějak jednat, kauzálně nepơsobí samy naše psychologické stavy (jakkoli ji jistě ovlivňují), ani důvody, které nás ke zvolení alternativy přivedly, ${ }^{2}$ nýbrž příčinou a autorem volby je sám (substanční) volitel nadaný schopností „kontingentní sebedeterminace“. Dvořák v tomto smyslu rozvíjí př́íslušnou ontologii (druhá část knihy) a také zajímavou a dobře rozpracovanou teorii motivace (zejména 3 . a 4. kapitola poslední části).

Proti těmto hlavním liniím Dvořákových úvah nemám vážných námitek. Domnívám se naopak, že ladí se zkušeností. V momentech, kdy se ve svém rozhodování cítíme svobodní, přece sami sebe zakoušíme jako aktivní činitele a původce volby, nikoli jako pouhé pasivní loutky deterministických psychologických faktorů. A dovolím si poznamenat, že vzhledem k tomuto zkušenostnímu základu Dvořákovy primární teze se budou její oponenti nutně nalézat v prekérní situaci. Vždyt', jak připomíná např. Charles Taylor, dobrá teorie (alespoň nejde-li o teorii normativní, nýbrž explanační) by neměla protiřečit způsobu, jak fakticky prožíváme své životy. ${ }^{3}$

Táž metodologická zásada mě nicméně nutí vyjádřit v přítomné studii určitý dílčí nesouhlas, totiž svou nespokojenost s Dvořákovým příliš paušálním a nediferencovaným odmítnutím kompatibilismu. Náš autor (jak dále podrobně ukážu) staví na předpokladu, že volba je svobodná pouze tehdy, mohl-li se volitel (za týchž okolností) rozhodnout jinak. Proti tomu však svědčí zkušenost volby, při které sice na jedné straně víme, že z nějakých, např. i morálních důvodů, v dané situaci rozhodně nejsme schopni volit jinak, avšak zároveň se - na druhé straně - jedná o naše vlastní rozhodnutí, k němuž jsme vedeni svým osobním přesvědčením (rozhodujeme se „sami ze sebe“ a na základě svého rozumu), takže nepochybujeme o svobodné povaze své volby. V podobných případech

2 Ty mohou být sice pokládány za finální příčiny (v aristotelském smyslu slova), nikoli však za příčiny eficientní. Tamtéž, s. 166.

3 Taylor (2001, s. 58). 
je, myslím, svoboda volby slučitelná (srov. termín „kompatibilismus“) s nutností, tj. s faktem, že volitel nemůže volit jinak; resp. že danou volbu ceteris paribus ${ }^{4}$ nemůže neučinit.

Záměrem mé statě je vést $\mathrm{v}$ tomto směru s Petrem Dvořákem diskusi, tj. vznést námitky proti jeho inkompatibilismu. Zkraje bude možná užitečné připomenout, jak mnohotvárná teoretická stanoviska nazývaná „kompatibilismus“ a „inkompatibilismus“ vztahují pojem svobody k determinismu. Determinismus obecně ř́ká, že vše, co nastává, nastává s nutností. Kauzální a nomologický determinismus upřesňuje, že vše, co nastává, je na základě přírodních zákonů nutným důsledkem předchozího stavu věcí. Kompatibilismus je pak stanoviskem, podle nějž deterministická povaha reality neodstraňuje morální odpovědnost, nebở nevylučuje existenci svobodné vůle, resp. jejích aktů, svobodných rozhodnutí. Naopak podle inkompatibilismu existuje rozpor mezi determinismem a předpokladem volní svobody, potažmo i odpovědnosti (svoboda vůle tvoří podmínku morální odpovědnosti). Pokud inkompatibilista navíc míní, že svoboda vůle existuje, nazýváme jej libertariánem.

Petr Dvořák je (libertariánský) inkompatibilista. Bere totiž za své tvrzení, že
„,..vyskytne-li se alespoň jedno svobodné jednání, nemůže skutečnost existovat tak, jak tvrdí determinismus. Jinými slovy, determinismus musí být nepravdivý. A naopak, je-li pravdivý determinismus, neexistuje žádné svobodné jed- nání, a jelikož jen za takové jednání může být jeho činitel odpovědný, žádný činitel není za nic morálně odpovědný.“5

Proč podle Dvořáka determinismus vylučuje svobodu? Je tomu tak proto, že nezbytnou podmínkou svobody je volitelova „sebedeterminace“ $\mathrm{k}$ volbě, resp. k pojmutí intence, přičemž tato podmínka „zahrnuje navíc i skutečnost, že činitel nemůže být k sebedeterminaci determino-

4 „Za ostatních (podmínek) rovných“, tj. za týchž okolností; v téže situaci.

5 Dvořák (2020, s. 25). 
ván něčím či někým od něj odlišným “, ${ }^{6}$ jak tomu ovšem vždy je podle determinismu. Dvořák nabízí dvě různá zdůvodnění svého požadavku, aby jednající, má-li být ve své volbě vskutku svobodný, nebyl ke své sebedeterminaci sám determinován ničím od sebe odlišným. Jedním důvodem je, že jinak by údajná (kompatibilisticky myšlená) svoboda nestačila k morální odpovědnosti za danou volbu, takže by se nejednalo o skutečnou svobodu. ${ }^{7}$ Druhým důvodem je tzv. princip alternativních možností, který $\mathrm{v}$ př́padě svobodných aktérů nepřipouští zmíněnou „vnější " predeterminaci. ${ }^{8}$ Probereme obě tyto argumentační linie, avšak začneme od posledně jmenované zásady, které zde budeme věnovat většinu prostoru.

\section{Princip alternativních možností vs. kompatibilismus}

Petr Dvořák soudí, že „vnější determinace, která činitele determinuje k tomu, aby se sám určitým způsobem vymezil, ruší svobodu“. ${ }^{9} \mathrm{Na}$ čem toto své mínění staví? Především na tom, čemu se běžně ř́ká princip alternativních možností (dále jen $\mathrm{PAP}=$ principle of alternate possibilities). Podle této zásady je aktér morálně odpovědný za svou volbu jen tehdy, pokud mohl volit jinak. ${ }^{10}$ Jelikož morální odpovědnost předpokládá svobodu rozhodování, a svoboda nás zajímá, právě nakolik tvoří předpoklad morální odpovědnosti, lze PAP stejně dobře formulovat i takto: Volba je svobodná jen tehdy, mohl-li se aktér rozhodnout jinak.

V tomto duchu Dvořák zdůrazňuje, že „klíčovou“ či „,nutnou i postačující podmínkou“ svobody rozhodování je právě „existence alternativních možností “. ${ }^{11} \mathrm{Na}$ tomto předpokladu náš autor staví jasný argument proti slučitelnosti volitelovy svobody s jeho vnější predeterminací:

6 Tamtéž, s. 18.

7 Tamtéž, s. 167-170.

8 Tamtéž, s. 18-23.

9 Tamtéž, s. 19.

10 Ačkoli se tradičně při formulaci PAPu hovoří o možnosti jednat (act) jinak, domnívám se (z důvodů, jež v dalším vyjdou najevo), že - chceme-li být přesní - jde spíše o možnost chtít, volit či rozhodnout se jinak. V tomto duchu formuluje PAP např. Stewart Goetz: „An agent is morally responsible for his choice at time $t$ only if he was free at to choose otherwise." Goetz (2005, s. 83).

11 Dvořák (2020, s. 23 včetně pozn. 9). 
„To, že k této vnější determinaci nemůže dojít, totiž plyne (...) z podmínky existence alternativních možností: pokud činitel je s to za přesně stejných kauzálních okolností jednat jinak, než jedná, pak z toho plyne, že k vlastní determinaci jednat tak a tak není ničím determinován, jinak by tuto alternativní možnost neměl."12

Jelikož souhlasím, že determinismus (či, přesněji, deterministické fungování veškeré skutečnosti) by vylučoval alternativní možnosti voleb, považuji Dvořákův argument za platný v tom smyslu, že závěr opravdu plyne z daných předpokladů. Návrh klasických kompatibilistů, že determinismus nevylučuje alternativní možnosti, se mi nezdá přesvědčivý. $\mathrm{V}$ čem tato starší kompatibilistická strategie spočívala?

Myšlenka je jednoduchá: Svobodní jsme prostě tehdy, činíme-li to, co činit chceme. ${ }^{13}$ Determinismus prý tudíž připouští, že aktér by mohl jednat jinak. Vždyt’ říci, že by mohl jednat jinak, neznamená nic více, než že by jinak jednal, kdyby se pro to rozhodl. ${ }^{14}$ Např. žíznivec sice $z a$ určitých okolností nutně chce pít a nutně pije, avšak za nějakých jiných okolností, např. kdyby šla historie jinak a on v daný moment nežíznil, by pít nechtěl - a tudíž nepil. Za dané situace tedy sice s nutností platí, že se rozhoduje pít a pije, avšak zároveň platí, že by nepil, $k d y b y$ se tak rozhodl.

Jak je vidět, tato „kondicionální“ či „hypotetická analýza“"15 svobody v ústech klasického kompatibilisty předpokládá, že chce-li aktér za určitých okolností nějak jednat, nemůže za týchž okolností chtít nic jiného. Aktérovo chtění jednat jinak by nastalo jen za odlišných okolností. A právě jen v tomto omezeném smyslu podle klasického kompatibilisty platí, že by činitel - navzdory determinismu - mohl jednat jinak. I za deterministických předpoklado̊ je totiž mnohdy pravdou, že by jednal jinak, kdyby - za odlišných podmínek - jednat jinak chtěl.

12 Tamtéž, s. 19.

13 David Hume: „By liberty, then, we can only mean a power of acting or not acting, according to the determinations of the will; that is, if we choose to remain at rest, we may; if we choose to move, we also may." Hume (1975, s. 95).

14 Srov. např. Ayer (1972, s. 271-283).

15 Tento termín použivá libertarián Robert Kane. Kane (2005, s. 16; s. 26-31). 
Proč tato s determinismem slučitelná „možnost jednat jinak“ nediskvalifikuje Dvořákův argument? Volit a jednat jednak jinak by (v analyzované perspektivě) pro určitého volitele $\mathrm{v}$ času $t$ bylo možné jen za odlišné situace v témže času $t$ (tj. nikoli ceteris paribus). Nehledě na fakt, že takováto „jiná situace“ je v deterministickém světě kauzálně nedostupná, je zřejmé, že možnost „,jednat jinak“, kterou disponuje klasický kompatibilismus, rozhodně není možností jednat jinak „za přesně stejných kauzálních okolností“, jak je to ovšem výslovně zmíněno v premise Dvořákova argumentu. Postřehy klasických kompatibilistů tudíž nejsou s to zpochybnit, že inkompatibilistický závěr z daných premis opravdu plyne. Determinismus vylučuje možnost jednat ceteris paribus jinak. Z PAPu plyne inkompatibilismus.

U klasického kompatibilismu se ještě na moment pozdržme. Představme si, že aktér jedná, jak jednat chce. Rozlišme v této situaci chtění (volici), a na něm založené jednání. Nevýhodou klasického kompatibilismu je, že vysvětluje pouze svobodu jednání: ta prý tkví ve shodě s aktérovým chtěním. Zůstává však otázkou, v jakém smyslu vůbec může být svobodným samo chtění. Tato otázka je ovšem podstatná, zkoumáme-li svobodnou vůli (free will). A klasický kompatibilismus na ni neodpovídá. Aby tedy inkompatibilista zřetelně „odfiltroval“ kompatibilistický přelud alternativních možností volby, je pro něj užitečné při definování svobody nezůstat jen u požadavku možnosti jednat jinak, ale musí svobodu vázat na možnost chtít, volit či rozhodnout se jinak. Toho si je Petr Dvořák patrně vědom, a proto výslovně hovoří o svobodě rozhodování (nejen jednání); definuje ji následovně:

\section{„Činitel $S$ za daných kauzálních okolností $O$ činí rozhod- nutí $x$, které je svobodné, právě tehdy, když je možné, aby $S$ v okolnostech $O$ neučinil rozhodnutí $x$. ${ }^{* 16}$}

Pokud PAP chápeme takto, pak ovšem opravdu nepřipouští žádný kompatibilismus.

V tomto boděje však třeba zároveň konstatovat, že se Dvořák nepokusil pro PAP, ani pro svou verzi PAPu, uvést žádný argument. A to je zaráže-

16 Dvořák (2020, s. 23). 
jící především vzhledem k výše referovanému faktu, že totiž právě PAP je premisou, na které týž autor ve své knize zakládá svůj inkompatibilismus (ve smyslu popření kompatibilismu jako takového). Nadále proto budu postupovat tak, že $\mathrm{v}$ hrubých rysech připomenu dosavadní filosofickou diskusi o pravdivosti PAPu a představím argumenty vyvracející paušální platnost této zásady (čímž zpochybním Dvořákủv inkompatibilismus).

\section{Princip alternativních možností a Frankfurtův protipříklad}

Dvořákova kniha vytváří dojem, že kompatibilismus existuje toliko ve své klasické verzi, jež (jak jsme viděli výše) při popisu svobody operuje s aktérovými alternativními možnostmi (s možností ,jednat jinak“) ${ }^{17}$. Náš autor tak nechává bez povšimnutí hlavní linii ve vývoji kompatibilismu za posledních cca 50 let, která je vyznačena jmény jako H. G. Frankfurt či J. M. Fischer a od klasického kompatibilismu se liší především výslovným odmítáním principu alternativních možností. Nyní zde připomenu alespoň nejznámější linii této neuvěřitelně rozsáhlé diskuse.

Představme si, nabádá nás Harry G. Frankfurt ve svém slavném článku z r. 1969, že Black chce, aby Jones uskutečnil určitou volbu. Black je schopen pomocí technických prostředků kontrolovat Jonesův mozek, takže pokud by se snad schylovalo k tomu, že by Jones volil jinak, Black by zasáhl a způsobil by, aby se Jones rozhodl v souladu s jeho přáním. Jones nicméně tuto volbu činí sám od sebe, takže Black nezasahuje. Pointou př́iběhu je, že ačkoli Jones vzhledem k Blackově kontrole nemůže volit jinak, přesto je za svou volbu odpovědný, nakolik ji totiž činí sám od sebe, bez nucení a bez Blackova zásahu. ${ }^{18}$ Jelikož však morálně odpovědní jsme výhradně za volby svobodné, Jones, ač nemůže volit jinak, činí svou volbu svobodně - a PAP tudíž neplatí.

Dejme tomu, že Jonesova volba je z etického hlediska špatná. ${ }^{19}$ Ačkoli je Frankfurtovo vyprávění působivé, lze se domnívat, že je Jones zatížen morální odpovědností proto, že - nemohl-li více - mohl (a měl!) přinejmenším donutit Blacka k zásahu, tj. nečinit danou volbu sám od sebe.

17 Tamtéž, s. 40.

18 Frankfurt (1969, s. 835-836).

19 Např. David Widerker Frankfurtovu imaginaci upřesňuje v tom smyslu, že Jones se rozhoduje zabít Smithe. Widerker (1995, s. 247-261). 
Pak by ovšem Jonesova odpovědnost a svoboda přece jen závisely na možnosti jednat jinak (totiž tak, aby Black musel zasáhnout). Je tudíž Frankfurtův argument neúspěšný?

Frankfurtův stoupenec John Martin Fischer uznává, že Jones byl s to vyprovokovat Blackovu intervenci. Dodává však, že ji nemohl podnítit svou dobrovolnou volbou, ale leda „pouhým nedobrovolným projevem nějakého znamení, jímž může být např. „neurologický vzorec v mozku“. Jonesova schopnost zachovat se jinak není ničím více než jen „schopností dát nedobrovolně odlišné znamení", které by Black vnímal jako impuls k intervenci. ${ }^{20}$ Takové „znamení“ je Jonesovou „zcela nedobrovolnou indikací budoucí volby činit jinak (v př́ípadě, že mu nebude zabráněno).“ „Jestliže Black uvidí předběžné znamení, může intervenovat před jakoukoli [Jonesovou] dobrovolnou aktivitou. " ${ }^{21}$ Neexistuje tu tedy žádná možnost dobrovolně volit jinak, na které by Jonesova morální odpovědnost mohla záviset.

Z toho popisu je ovšem patrné, že Fischerův scénář se odehrává $\mathrm{v}$ deterministickém rámci. Kdyby totiž Jonesova psychologie nefungovala deterministicky, Black by na základě pozorovaného fyzického stavu, např. stavu mozku, nemohl vědět, že se může zdržet intervence, čili že se Jones následně (tak jako tak) rozhodne kýženým způsobem.

Předpokládá-li ovšem frankfurtovská strategie determinismus, je nasnadě následující pádná námitka. Argument již předpokládá to, co by měl dokazovat, totiž slučitelnost svobody s determinismem..$^{22}$ V̌̌dyt inkompatibilistický čtenár př́běhu nemá - vzhledem k jeho deterministické podobě - důvod připouštět existenci Jonesovy svobody, kterou ovšem Frankfurtův protipř́klad potřebuje pro svou pointu, totiž aby se ona svoboda ukázala být slučitelnou s Blackovou kontrolou vylučující alternativní možnosti. Frankfurtovský argument nijak nebrání inkompatibilistovi tvrdit, že Jonesova svoboda a morální odpovědnost již byly eliminovány samotným deterministickým rámcem př́iběhu, a nemohou tudíž zdařile koexistovat s Blackovým vyloučením alternativní volby, jak si to přál Frankfurt. ${ }^{23}$

20 Fischer (2002, s. 288-289).

21 Fischer (2012a, s. 128).

22 Kane (1985, s. 51; 1994, s. 142-145, 191-192); Widerker (1995); Ginet (1996).

23 Goetz (2005, s. 83-105). 
J. M. Fischer nakonec - vzhledem k uvedené námitce - činí taktický ústupek. Jelikož v argumentaci pro kompatibilismus nemůže předpokládat jak determinismus, tak zároveň i morální odpovědnost, je nucen se jedné z obou rekvizit zříci. Ve výsledné verzi svého argumentu sice nadále předpokládá deterministický rámec př́iběhu, avšak upouští od předpokladu Jonesovy morální odpovědnosti. Nová formulace frankfurtovského argumentu tak dospívá ke slabšímu výsledku, který ř́ká: jestliže Jones není morálně odpovědný za svou volbu, nemůže za to chybění alternativních možností. ${ }^{24}$ Tento „iniciální závěr “25 znamená, že eliminace alternativních možností je někdy (jako právě v Jonesově případu) pro otázku morální odpovědnosti irelevantní. ${ }^{26}$

Šiky Fischerových oponentů samozřejmě nelení a čile atakují premisy $^{27}$ nebo i logickou formu ${ }^{28}$ jeho vylepšeného argumentu. My však zde můžeme ponechat stranou jak strukturu argumentu, tak i dosavadní námitky oponentů. I když totiž připustíme správnost argumentu (datum non concessum ${ }^{29}$ ) včetně řečeného ,iniciálního závěru“, PAP zůstává nedotčen, nebơ je s tímto závěrem slučitelný, jak nyní ukážu.

Ve vyumělkovaných frankfurtovských př́bězích je sice (dejme tomu) eliminace alternativ, působená Blackem, irelevantní pro otázku Jonesovy odpovědnosti, avšak to inkompatibilistovi nijak nebrání tvrdit, že v podobných př́ípadech zde ovšem žádná morální odpovědnost neexistuje (Fischer ji, jak už víme, v premisách nepředpokládá - a ani v závěru se neobjevuje). A tudíž ovšem může zároveň stále a neohroženě platit, že kde naopak morální odpovědnost za volbu vskutku existuje, tam musí pro volitele existovat alternativní možnosti (jak říká PAP). Řečeno ve zkratce: věta „eliminace alternativních možností je v některé situaci irelevantní pro odpovědnost“ a věta „odpovědnost vždy implikuje alternativní možnosti“ se vzájemně nevylučují. Ukážu to na příkladu.

\footnotetext{
24 Fischer (2010, s. 328).

25 Tamtéž, s. 324.

26 Tamtéž, s. 335.

27 Palmer (2014); Cohen (2016); Tierney (2014).

28 Widerker \& Goetz (2013).

29 „Dejme tomu“. Obrat vyjadřuje situaci, v níž takticky akceptujeme některý předpoklad našeho partnera v diskusi, avšak spíše proto, že toto tvrzení v daný moment nepotřebujeme vyvracet, než že bychom je skutečně potvrzovali.
} 
Představme si chlapce, který krade v samoobsluze, přičemž fakt, že za své jednání nenese morální odpovědnost, se nezakládá na tom, že by snad nemohl volit jinak (dejme tomu, že by mohl), ale spíše na tom, že byl špatně vychován. Kdyby se tedy do př́běhu navíc zapojil Black (se svou neurální kontrolou) a eliminoval chlapcovu možnost volit jinak, byla by tato eliminace pro otázku morální odpovědnosti irelevantní. Přesto ale může zároveň platit, že kdykoli někdo (náš hoch či kdokoli jiný) vskutku je za svou volbu morálně odpovědný, jsou zde i alternativní možnosti (= PAP). Podobně např. v případě ochrnutého člověka zavřeného v těsné kabině může být pravdou, že nedostatek prostoru je irelevantní pro fakt, že nemůže chodit, avšak přesto zároveň zůstává pravdou, že chodí-li někdo, musí mít pro chůzi prostor.

Fischer ze svého „iniciálního závěru“ dále vyvozuje „generalizovaný závěr“, který ř́ká, že pokud determinismus odstraňuje odpovědnost, nečiní to eliminací alternativních možností. ${ }^{30}$

Toto tvrzení je z „iniciálního závěru“ získáno nikoli strukturovaným argumentem ani s pomocí dalších premis, nýbrž, jak Fischer uvádí, „přirozeně a př́mo“ (naturally and straightforwardly). ${ }^{31}$ Mám dojem, že k tomuto kroku Fischer není oprávněn. Kdyby Fischer svou verzí frankfurtovského příběhu dokázal, že každá eliminace alternativních možností je irelevantní vzhledem k odpovědnosti, pak by z toho nepochybně vyplývalo, že tedy rovněž i ta eliminace, která je spojena s determinismem. Avšak Fischer dokázal maximálně jen to, ${ }^{32}$ že některá eliminace (totiž přinejmenším ta, kterou působí Black) je irelevantní pro morální odpovědnost. ${ }^{33}$ Odtud ovšem neplyne, že by stejně „neškodnou“ či irelevantní musela být i ta eliminace alternativních možností, která by byla důsledkem deterministického fungování světa. Inkompatibilista není ni-

30 Fischer (2010, s. 328, 335).

31 Tamtéž, s. 335 .

32 Pochybuji vlastně, že daný argument vůbec něco dokazuje. Nepřijímám totiž jeho skryté fyzikalistické předpoklady. Pro analýzu tohoto typu zde však není prostor. Omezuji se jen na poukaz, že z „iniciálního závěru“ (i kdybychom ho Fischerovi uznali) neplyne ani neplatnost PAPu, ani "generalizovaný závěr“.

33 Sám Fischer uzavírá: „....there are cases in which the agent's lack of access to a certain sort of alternative possibility appears to be irrelevant to his or her status as morally responsible for the relevant behavior.“ Fischer, jak vidno, jen říká, že „existují takové př́ípady“, kdy je nepřítomnost alternativ irelevantní pro aktérovu odpovědnost. Nemůže tvrdit, že je irelevantní ve všech př́padech. Fischer (2010, s. 335). 
kterak nucen Fischerovi připustit, že by se daná irelevance měla z Blackovy a Jonesovy situace zbůhdarma rozššřit rovnou na celé univerzum.

\section{Svoboda volby bez alternativních možností}

Ačkoli je obhajoba frankfurtovského protipříkladu nesnadným, a možná neproveditelným úkolem, jak jsme právě viděli, přesto se zároveň domnívám, že stojí za to být k Frankfurtovu příběhu vnímaví a všimnout si jeho podstatného poselství. Týká se faktu, že k morální přičitatelnosti volby (a následného jednání) někdy stačí, aby racionální aktér - podobně jako právě např. Jones - činil svou volbu sám od sebe (on his own). ${ }^{34}$ To, že se někdo rozhodl sám od sebe, a tudíž se zdá být za svou volbu vskutku odpovědný, samo o sobě ještě nic neř́ká o existenci nějakých alternativních možností! V tomto směru však nyní můžeme opustit zbytečně sofistikované a kontroverzní př́běhy o Jonesovi a Blackovi a věnovat pozornost jiné, v podstatě velmi př́ibuzné, jen daleko jednodušší a přesvědčivější linii Frankfurtovy a Fischerovy argumentace.

Harry Frankfurt hovořil o tzv. volní nutnosti (volitional necessity), jež nijak neprotiřečí svobodě. Tuto nutnost odlišuje od psychologické determinace, s níž např. „nedobrovolný narkoman“ - navzdory svým dobrým předsevzetím - opět bere svou drogu a koná tak, co v nějakém významném smyslu slova dělat nechce. Subjekt „volní nutnosti“ naopak činí to, co on sám chce tak jednoznačně, že ani není s to chtít jinak. ${ }^{35} \mathrm{Ve}$ volné návaznosti na Frankfurtovy úvahy můžeme volní nutnost definovat takto: Aktérova volba je př́padem volní nutnosti právě tehdy, pokud platí, že i kdyby (za dané situace) mohl jednat jinak, kdyby jen chtěl, přece (za téže situace) není schopen chtít jednat jinak.

Že je volní nutnost dobře slučitelná s morální odpovědností, je vidět na př́íkladu, jejž uvádějí John Martin Fischer a Mark Ravizza: Matouš, jelikož je dobrým a zodpovědným člověkem, v určité situaci nemůže jinak než zachránit tonoucí dítě. Filosofickou pointou tohoto mini-př́iběhu je, že $i$ kdybychom připustili, že Matouš mluví pravdu, když tvrdí, že

34 Frankfurt Jonesově volbě a jednání ř́ká: „If he does it on his own, however, his moral responsibility for doing it is not affected by the fact that Black was lurking in the background with sinister intent, since this intent never comes into play." Frankfurt (1969, s. 836).

35 Frankfurt (1998, s. 86-88; 1999, s. 111). 
v daný moment nebyl s to volit jinak, budeme $i$ presto jeho čin považovat za morálně dobrý a chvályhodný, což znamená, že Matoušovi vzhledem k jeho volbě připisujeme morální odpovědnost, jejímž předpokladem je ovšem svoboda rozhodování. ${ }^{36}$ PAP tudíž neplatí.

Můžeme si v tomto kontextu připomenout metodologickou zásadu, jež byla zmíněna v Úvodu. Dobrá teorie vysvětluje naši zkušenost, aniž by jí protiřečila. Zde se jedná o morální zkušenost. Při určitých volbách na jedné straně víme, že z etických důvodů nejsme schopni rozhodnout se jinak, avšak přesto - na straně druhé - zároveň své rozhodnutí zakoušíme jako svobodné: činíme je totiž sami od sebe a na základě vlastního přesvědčení. Naše teorie by neměla tuto zakoušenou či prožívanou konjunkci nutnosti a svobody popírat, jak se toho dopouští obhájce obecné platnosti PAPu.

Lze k tomu navíc dodat, že ztotožnění svobody volby se schopností „volit jinak“ klade svobodu a morálku proti sobě: Je-li někdo morálně vysoko stojící osobou, jako např. Matouš, jenž „nemohl jinak“, stává se proto člověkem nesvobodným. Stoupenec PAPu je nucen tvrdit, že kdyby Matouš nebyl tolik morálně dobrým a byl by naopak schopen ponechat tonoucí dítě svému osudu, byl by díky tomu svobodnější (byl by totiž s to volit jinak, než jak volil). Jelikož však bude čtenář pravděpodobně souhlasit, že v rozvoji lidského života naopak osobní morálka a vnitřní svoboda rostou společně, odmítne, jak doufám, PAP, který je zdrojem stěží přijatelných důsledků.

Jaké jsou filosofické důsledky naznačeného spojení nutnosti volby se svobodou též volby? Snad opuštění PAPu a nevyhnutelné přijetí kompatibilismu? Robert Kane se pokusil najít únikovou cestu. Volba sice někdy může být nutná i svobodná zároveň, uznává Kane, avšak jedině a výlučně v těch případech, kdy aktérova povaha, která je zdrojem dané psychologické nutnosti, vznikla přispěním jeho nenutných voleb v předchozím životě, při nichž aktér ovšem „mohl jinak“. Aktérova determinující povaha byla zformována jeho dřívějšími nedeterminovanými volbami, tzv. „sebeformujícími akty“ (self-forming actions) či „sebeformujícími volicemi“ (self-forming willings). ${ }^{37} \mathrm{~V}$ tomto smyslu i svoboda oné volby, jež

36 Fischer \& Ravizza (1991, s. 259).

37 Kane (1996, s. 74, s. 125; 2005, s. 129-131). 
je nakonec determinovanou a nutnou, podle Kanea závisí na možnostech „volit jinak“v předchozím životě, totiž při dřívější aktérově sebeformaci.

Co k tomu říci? Popravdě řečeno nikdy jsem u Kanea nenalezl argument, proč by zkušenost svobody neměla být u nutné volby stejně respektována i za předpokladu, že je volitelova determinující povaha spíše důsledkem toho, jak byl tento aktér bez své libovůle „utvořen“, at už za jeho povahu může dědičnost, souhra vlivů, Bůh, výchova - či to vše dohromady. Osobě mohlo být „souzeno“ nahlížet morální důvody tak zřetelně, že - při své povaze - činí svou volbu s nutností, a přesto (či dokonce právě proto) volí autonomně a podle vlastního rozumu, tj. svobodně (viz následující oddíl). Pro uznání takovéto svobody nejsou sebeformující akty absolutně nutným předpokladem. K tomu se zde vrátím v 7. oddílu. Nyní je třeba zodpovědět, co tedy - z hlediska kompatibilis$\mathrm{mu}$ - činí popsaný typ voleb svobodnými.

\section{Podstata svobody a kauzalita činitele}

Netkví-li svoboda v možnosti „volit jinak“, co jiného pak tvoří její podstatu? Uvažujme nejprve o úloze racionality. Volní nutnost, jež funguje na základě rozumových důvodů, je třeba odlišit od emoční determinace. V případě volní nutnosti nejde o to, že bychom byli bezmocnými „obětmi“ svých citů. Nutnost naší volby souvisí s rozumem chápanými dưvo$d y$ pro určité jednání, které by byly rozhodující i v př́ípadě, že by emoční inklinace k danému jednání byla překonatelná. Jak říká Susan Wolfová: „Jedním [možným] vysvětlením, proč nějaká aktérka není schopna jednat jinak, je, že je zcela racionální učinit to, co činit zamýšlí, a ona je př́liš racionální, než aby tento fakt ignorovala.“38

K tomu, aby byla volba svobodná, se zdají být nezbytnými tři charakteristiky - a racionalita je jednou z nich. Za prvé, má volba je svobodná pouze za podmínky, že se opravdu jedná o mou volbu (nejsem např. obětí psychologické manipulace ze strany jiné osoby či post-hypnotické sugesce). Za druhé, volba musí být dobrovolná, nikoli nap̌r. vynucená hrozbou. Jelikož by však tyto podmínky mohla při svém rozhodování splňovat i zvířata (např. Micčina volba pít mléko může být opravdu jejím

38 Wolf (1993, s. 70). 
vlastním rozhodnutím, a navíc zcela dobrovolným a nevynuceným), je třeba připojit, podmínku třetí: svobodná volba je vedena rozumem poznanými důvody. Tato třetí podmínka tvoří kritérium, na základě kterého např. přisuzujeme morální odpovědnost a svobodu Matoušovi, a nikoli třeba záchranářskému psu, ${ }^{39}$ třebaže se dejme tomu oba tito hrdinové rozhodují $\mathrm{k}$ akci sami od sebe a dobrovolně. Jsou-li všechny tři podmínky splněny, pak je volba svobodnou nezávisle na tom, zda aktér je či není s to volit jinak.

Požadavek racionality bývá zpochybňován filosofy, kteřísvobodu volby vidí spíše v tom, že dané rozhodnutí znamená autentické „sebevyjádření" (self-expression) jednajícího. Tuto teorii lze ilustrovat následovně: Chlapci Huckleberrymu Finnovi (postavě známého Twainova příběhu) jeho výchovou zformované svědomí ř́kalo, že uprchlý černý otrok Jim by měl být navrácen „právoplatné“ majitelce. Huck však navzdory tomu pomáhá Jimovi při jeho útěku na svobodný Sever. Ačkoli hoch jakožto morální aktér nejedná ve shodě se svým rozumovým přesvědčením, nýbrž naopak v rozporu s ním, přesto čtenář jeho jednání hodnotí jako morálně dobré a chvályhodné. Podmínkou morální odpovědnosti tudíž není racionalita volby, uzavírají stoupenci expresivismu..$^{40}$

Osobně pochybuji, že je takováto argumentace dostatečná. Huck byl ve své spontánní volbě veden určitými hodnotami, jimiž mohly být např. přátelství, svoboda, lidská důstojnost či solidarita. Přestože nedisponoval přesným slovníkem hodnot, poznával tyto vůdčí hodnoty v nějaké míře i jakožto rozumová bytost, nejen čistě „animálně“. A tak tomu mohlo být bez ohledu na (protichůdné) závěry Huckových explicitních morálních úvah.

Výměr svobody, který se obejde bez PAPu, může být formulován i v termínech kauzality: Má volba je svobodná v tom smyslu, že mou vůli - či, přesněji řečeno, mne jakožto „uživatele“ vůle - k rozhodnutí př́mo nedeterminovaly žádné eficientní ${ }^{41}$ př́činy kromě mne samého.

39 Existuje historický případ psa jménem Guinefort, jehož volba zachránit dítě byla hodnocena jako záslužná v morálním smyslu slova a chrt byl lokálně uctíván jako svatý (a dokonce jako mučedník, nebot’ jeho pán, otec zraněného dítěte, Guineforta omylem zaměnil s útočníkem a zabil jej). Inkvizice nicméně kult sv. Guineforta potírala jako pověru. Schmitt (2007).

40 Sripada (2016, s. 1214).

41 Použivám zde aristotelskou klasifikaci příčin. Eficientní neboli účinná příčina je př́činou 
Tím není vyloučeno, že mohu být ke své volní sebedeterminaci nějakými eficientními př́činami nepřímo predeterminován. Takovými eficientními příčinami (souvisejícími např. s genetikou, výchovou či dalšími vlivy) totiž mohla být zformována má povaha a mentalita. Díky té pak za některé situace nemohu nevidět důvody (např. morální) pro danou volbu a odpovídám na ně s nutností. Je pravdou, že mou volbu tak v jistém smyslu př́mo působí (kromě mne jako eficientní př́činy) i ony důvody, avšak ty zde hrají roli finálníit (nikoli eficientní) příčiny.

Toto pojetí svobody je $\mathrm{v}$ podstatě tomistické43 ${ }^{3}$ dokonale ladí s Dvořákovou ideou „kauzality činitele“. Sám Dvořák nic nenamítá proti tomu, aby bylo rozlišení eficientní a finální kauzality takto aplikováno a finální kauzalita byla do popisu svobodného rozhodnutí v uvedeném smyslu zahrnuta. Jakožto inkompatibilista a libertartián jen trvá na tom, že - má-li být volice svobodná -, nesmí být fungování finální kauzality provázeno determinující nutností. ${ }^{44}$ Dvořákovy důvody už známe. Prvním z nich byl PAP, který jsme zde ovšem již - jakožto univerzální princip - dostatečně diskvalifikovali v minulém oddílu. Podívejme se v následující sekci na druhý základ Dvořákova inkompatibilismu, totiž na požadavek, aby svoboda volby v našem popisu tvořila funkční základ volitelovy morální odpovědnosti.

\section{Morální odpovědnost}

Petr Dvořák - v návaznosti na Derka Perebooma - rozlišuje dvojí typ morální odpovědnosti. Odpovědnost „ve slabším smyslu“ lze přisuzovat voliteli, který byl ke své sebedeterminaci predeterminován jinými příčinami, než je on sám. ${ }^{45}$ Podobný pojem odpovědnosti vyjadřují někteří soudobí autoři termínem „přičitatelnost“ (attributability). ${ }^{46}$ Dvořák

v běžném smyslu slova (např. oheň v kamnech je účinnou příčinou toho, že se plotna rozehřívá; tenista je při podání eficientní př́ičinou pohybu míčku). Od eficientní příčiny se odlišuje (mj.) finální příčina, jež je tím, kvůli čemu činitel koná. Cíle, pro které jednáme, nás uvádějí v činnost jakožto finální příčiny této činnosti.

42 Viz předchozí poznámku.

43 Peroutka (2012; 2016).

44 Dvořák (2020, s. 166 včetně pozn. 140).

45 Tamtéž, s. 168-169, srov. s. 18).

46 Např. psychopatovi lze jeho problematické chování přičítat a negativně jej za ně morálně hodnotit, aniž by však za ně nesl morální odpovědnost (accountability). Shoemaker (2011). 
dává za příklad určitá morální hodnocení lidských charakterů, nakolik jsou namístě i v př́padě, že by hodnocená povaha byla pouhým výsledkem dědičnosti a výchovy; viz např. větu ,je sobec, ale nemůže za to“ ${ }^{.47}$ V podobné míře náš autor připouští kompatibilistům, že i lidská jednání, jež jsou zatížená odpovědností jen „ve slabším smyslu“, lze někdy morálně hodnotit. ${ }^{48}$

Petr Dvořák ovšem nevidí důvod, proč bychom ve své teorii měli tuto slabší odpovědnost vázat na pojem svobody. Nevidí, proč bychom jednání, za které aktér nemůže, měli nazývat svobodným. Skutečnou svobodu pojímá jako cosi, co se požaduje pro naši odpovědnost v silnějším smyslu slova. Tato silnější odpovědnost je založena na faktu, že jednající za svou volbu může, nebot' ke své volní sebedeterminaci nebyl s nutností predeterminován ničím, nad čím by sám neměl kontrolu. ${ }^{49} \mathrm{~V}$ tomto smyslu kontingentně determinuje sám sebe a je původním autorem své volby, a to bud' prímo, anebo díky své dřívější relevantní sebeformaci. ${ }^{50}$

Myslím, že právě zde se dostáváme $\mathrm{k}$ podstatnému a subtilnímu jádru neshody mezi kompatibilistou a inkompatibilistou. Libertarián bude trvat na tom, že přisuzování morální odpovědnosti pouze ve slabším smyslu (jak jej chápe Dvořák) nepřipouští svobodnou povahu dané volby. Kompatibilista bude naopak tvrdit, že i přisuzování odpovědnosti ve slabším smyslu může vyžadovat, abychom aktérově volbě připisovali skutečnou svobodu jako podmínku odpovědnosti (takže lze na tomto základě hovořit o volbách nutných i svobodných zároveň). Ačkoli zamýšlím argumentovat ve prospěch tohoto druhého stanoviska, naznačím nejprve jeho limity.

S Petrem Dvořákem a jinými libertariány souhlasím, že $\mathrm{v}$ případě voleb, které hodnotíme jako morálně špatné, pouhá slabá odpovědnost není skutečnou odpovědností a není důvod ji vázat na svobodu jako podmínku. Důvodem tohoto mého ústupku je, že o zlých volbách musíme uvažovat jinak než o volbách, jež jsou podle nás z etického hlediska v pořádku. Oba typy voleb stojí v jisté vzájemné disproporci či „asymetrii““.51

47 Dvořák (2020, s. 169).

48 Tamtéž, s. 168-169.

49 Srovnej tamtéž, s. 167.

50 Srovnej tamtéž, pozn. 145 na s. 169.

51 O „asymetrii“ hovoří Susan Wolf (1993, s. 69-79). 
Ta je dána pozoruhodným faktem, že zatímco z hodnocení volby jako morálně dobré neplyne, že měl aktér volit jinak, hodnocení volby jako zlé tento předpoklad samo sebou obnáší. A dále ovšem platí, že osobě, která měla volit jinak, smíme připisovat vinu jen tehdy, pokud se mohla rozhodnout jinak. ${ }^{22}$ Jinými slovy: jen a pouze volby zlé a vinu obnášející jsou volicemi, pro něž jsme nuceni uznat platnost PAPu. ${ }^{53}$

Z platnosti PAPu pro zlé volby ovšem dále plyne, že volitel, máme-li mu za zlé rozhodnutí přičítat odpovědnost a vinu, nemohl být k takové sebedeterminaci predeterminován „zvnějšku“, jak už víme z Dvořákova zdařilého argumentu, ${ }^{54}$ který jsem citoval výše (v druhém oddílu této studie). Predeterminovaný, tzn. nanejvýše jen slabě odpovědný vykonavatel zlé volby, ačkoli snad jeho povaha i volba mohou být negativně hodnoceny ${ }^{55}$ přece nenese morální odpovědnost v pravém smyslu slova.

Jinak je tomu ale u voleb, které hodnotíme jako morálně dobré! V jejich př́padě nepředpokládáme, že aktér měl volit jinak; nejsme pro ně nuceni předpokládat platnost PAPu (viz výše 4. oddíl). Nevidím tudíž důvod vyžadovat zde odpovědnost v silnějším smyslu (čili odpovědnost, která by byla př́ípadnou predeterminací odstraňována). Dvořák při svém požadavku silnější odpovědnosti argumentuje fakticitou, konkrétně „běžným chápáním“ obvyklým v oblasti „západní morálky“. ${ }^{56}$ To by (snad) bylo přiléhavé ohledně voleb eticky špatných, u nichž někdy predeterminace (čili „slabost“ odpovědnosti) opravdu bývá považována za omluvu. Neslyšel jsem však, že by v naší (či jiné) kultuře byly kdy někomu upírány uznání, chvála či úcta s odvoláním na předpoklad, že daná osoba nemůže za to, jak dobrým člověkem je - a že díky této své povaze beztak „nemohla jinak“.

52 Nebylo by fér, podotýká Mellema, obviňovat někoho, že nejednal tak, jak jednat nemohl. Mellema (2004, s. 40). O platnosti zásady ,ought implies can` by samozřejmě mohla být vedena dlouhá diskuse. Avšak jelikož v jedné stati nemohu vyřešit vše, budu zde předpokládat, že pokud aktér nejen jedná zle, ale je tím navíc i vinen (na rozdíl např. od duševně nemocného či nevědomého), pak tvrzení, že měl jednat jinak, zahrnuje předpoklad, že mohl jednat jinak.

53 Viz k tomu např. Copp (1997); Widerker (1991); Schnall (2001).

54 Dvořák (2020, s. 19).

55 Např. Julia Driver míní, že ačkoli psychopat není za své problematické chování morálně odpovědný, přesto mu může patřit hana. Psychopat je podle ní „morally appraisable, and the appropriate subject of blame, even though not morally responsible in virtue of lacking the relevant agential capacities“. Driver (2015, s. 171).

56 Dvořák (2020, s. 169). 
Zastavme se u tohoto rozdílu (jenž je odrazem výše zmíněné „asymetrie“). Představme si dvě osoby, z nichž ani jedna nemůže za svou povahu a obě na základě této své povahy činí určitou volbu s nutností („nemohou jinak“). Dejme tomu, že první osoba reaguje na situaci obecného ohrožení zbaběle, kdežto druhá naopak obětavě. Pokud se o první z obou osob dozvíme, že na základě své nezaviněné povahy nemohla jinak, budeme jakožto morální hodnotitelé ochotni její jednání omluvit (PAP totiž pro morálně špatné volby platí). Naproti tomu v případě druhé osoby jistě nebudeme popírat její morální zásluhu s odůvodněním, že na základě své dobré povahy nemohla jinak.

Dvořák požaduje „kontingenci“ sebedeterminace. Mám ale dojem, že druhá z popsaných osob si nezaslouží chválu o nic méně, než kdyby svou volbu činila „nahodile“ a ne nutně. Spíše naopak: nutnost zde značí pevný charakter. Údajně „slabá“ odpovědnost někdy neoslabuje, nýbrž naopak posiluje morální hodnocení volitele. Oslabuje či odstraňuje přesto jeho svobodu?

\section{Otázka intuice}

Uvažme případy volby, při níž na jedné straně zakoušíme, že na základě jasně nahlédnutých morálních důvodů $\mathrm{v}$ dané situaci nejsme schopni volit jinak, než jak volíme, avšak na druhé straně svou volbu prožíváme jako svobodnou, nebot ji činíme sami od sebe, dobrovolně a z vlastního přesvědčení. I kdybychom se při tom dověděli, že naše nahlížení morálních důvodů - a s tím spojená volní nutnost - nejsou výsledkem naší dřivější „libertariánské“ sebeformace („sebeformujících volic“v Kaneově smyslu), ale např. určité stránky naší vrozené - a výchovou rozvinuté povahy, či třeba Boží milosti, čili té či jiné predeterminace, stěží bychom kvưli tomu přestali svou volbu prožívat jako svobodnou.

V tomto př́íladu (i v mnoha předchozích) apeluji na cosi, čemu se v analytické filosofii obecně ř́ká „intuice“. Jedná se konkrétně o „intuice“, jež se týkají podstatných rysů našeho morálního života. Je apel na intuici dostatečným základem pro konstrukci teoretických řečení?

Odkaz k „pouhé“ intuici nabývá síly skutečného argumentu, pokud $\mathrm{k}$ němu připojíme (již výše zmiňovanou) metodologickou zásadu: naše 
teorie by neměla zbůhdarma popírat to, co v běžném životě tvoří inherentní předpoklad naší praxe (jakou je i prožívání či hodnocení morálně významných voleb). Morální zkušenost svobody, a tedy předpoklad svobody (byṫ před-teoretický či „intuitivní“) bychom měli jako filosofové respektovat, pokud tomu nic nebrání, a to platí i pro př́ípad volní nutnosti popsaný v předminulém odstavci. Petr Dvořák - a pokud vím ani nikdo jiný - nám nenabízí dostatečný důvod k opačnému postoji.

„Intuice“, o kterou v našich úvahách jde, je celkem jednoznačná a lze si ji uvědomit mnoha různými způsoby či v mnoha jejích verzích. Uvažme např. člověka, který na základě svého dobrého srdce nemohl jinak než nám z vlastního rozhodnutí nezištně pomoci v naší nouzi. Přestali bychom mu snad být vděční, kdybychom se dověděli, že své dobré srdce, resp. jeho relevantní aspekty, sám nestvořil „sebeformujícími akty“, nýbrž že „už je prostě takový“?

Volba je chvályhodná nejen tehdy, když takovou volbou člověk působí, že se stává morálně dobrým, ale také tehdy, když - v př́ípadě volní nutnosti - svou volbou projevuje, že je dobrým. Tak vnímáme sféru morálky. Libertarián tyto intuice připouští, ale nespokojuje se $\mathrm{s}$ jejich mírou: chce, aby „viděly“ více. Chce po nich př́lišs. Připojuje totiž jaksi navíc, že pokud má být morální aktér chválen za takovou svou volbu, jež byla nutným důsledkem jeho dobré povahy, musí být příslušné stránky této povahy výsledkem jeho minulých kontingentních „sebeformujících volic“ a „aktư“. Tento požadavek, který povážlivě zužuje pojmy odpovědnosti a svobody, ovšem pokládám za pouhý postulát.

Položme si nakonec otázku, zda diskuse o svobodě není sporem čistě terminologickým. Kompatibilisté disponují širším pojmem svobody než libertariáni. O co se tedy přeme? Není věcí jednoho každého, jak si který termín zavede a jak úzce či široce výraz „svoboda“ definuje? Nestojíme tak před diskusním „patem“? ${ }^{57}$ Není vše jen věcí pouhé stipulace?

Myslím, že nikoli. Jistě by např. nedávalo smysl přidělit slovu „svoboda“ tak široký význam, že bychom „svobodným“ nazývali i (zdánlivě nepředvídatelný) pohyb padajícího pírka, ani naopak tak úzký, že by podle nás byly „svobodnými“ výhradně jen volby neovlivněné žádnou emocí. Názvoslovná libovůle je zde omezena faktem, že pojem svobody vážeme

57 Fischer (2006, s. 119). 
především k našemu morálnímu životu, od něhož jsou ovšem určité perspektivy neoddělitelné. To musí být určující pro naše filosofické pojetí svobody. Má upozornění ohledně uvedených „intuicí“ (viz zejména první odstavec tohoto oddílu) ukazují, že libertariánské stanovisko tomuto požadavku nedostává.

\section{Závěr}

Petr Dvořák opírá svůj inkompatibilismus jednak o princip alternativních možností, a jednak o předpoklad, že se morální odpovědnost neslučuje s predeterminací (v uvedeném smyslu). Viděli jsme však, že důvody pro takové předpoklady platí jen $\mathrm{v}$ případě morálně špatných voleb. Jen zde má smysl argumentovat, že nikoho nelze vinit za jeho volbu, byl-li k ní predeterminován a nemohl proto volit jinak (viz zde 6. sekce). Existence morálně dobrých rozhodnutí, která jsou činěna svobodně i nutně zároveň, tedy není vyloučena; spíše se zdá, že jsou k mání důvody ji přijmout (jak jsem se v průběhu této statě pokusil ukázat).

$\mathrm{Z}$ provedených úvah tak plyne zvláštní typ kompatibilismu, který lze nazvat „,̌ástečným kompatibilismem“. $\mathrm{V}$ případě některých morálně dobrých voleb je jejich svoboda slučitelná s nutností a determinací. Naopak v prŕípadě volby, kterou hodnotíme jako morálně špatnou, takže aktér podle nás měl jednat jinak, platí, že pokud je vskutku vinen tím, že se jednat jinak nerozhodl, znamená to, že se mohl rozhodnout jednat jinak. Takové volby jsou tedy vždy „inkompatibilistické“, resp. „libertariánské“; vždyt゙ k provinění nemohl být volitel s nutností predeterminován.

Platí-li posledně jmenované zjištění, znamená to, že náš aktuální svět není kompatibilistický. Za svá morálně špatná rozhodnutí totiž někdy neseme vinu, jež ovšem není slučitelná s deterministickou povahou skutečnosti. Nicméně z množiny možných světů, v nichž se nikdo nikdy neprovinil, jsou některé světy kompatibilistické: totiž ty, ve kterých jsou všechny svobodné volby činěny s nutností. $\mathrm{V}$ tomto smyslu pokládám svobodu a determinismus za kompatibilní.

Tím ovšem neř́íkám, že by byl se svobodou slučitelný determinismus fyzikalistického typu. Vždyt volní nutnost, o níž jsme uvažovali, není beze 
zbytku důsledkem pouhé eficientní kauzality. Ve hře je i kauzalita čistě finální, totiž determinující přitažlivost rozumově poznaných důvodů, kterou nemáme důvod redukovat na mechanismus přímých eficientních prríčin. Různé eficientní prŕččny, odlišné od volitele samého, mohly jeho volbu způsobit nepřímo, tj. spíše ji predeterminovat než bezprostředně zapř́činit. Mohly předem formovat aktérovu povahu a racionalitu tak, aby za určitých okolností nahlédnul určité nezpochybnitelné důvody a přitakal jim s nutností. Př́mou eficientní příčinou výsledné volice však zůstává jen sám volitel, nakolik je s nutností veden oněmi poznanými důvody jakožto finálními př́činami své volby. Je to on, kdo činí své rozhodnutí. Kauzalita či sebedeterminace činitele vylučuje přímou determinaci jinými eficientními př́ćcinami, kterou ovšem tak či onak předpokládá stoupenec fyzikalismu.

Odmítnutím fyzikalismu nicméně není vyloučena nomologická a kauzální povaha (v širším významu termínů) příslušného determinismu. Nevím o žádném důkazu, že by nomologickým a aitiologickým slovníkem nemohl být popsán jiný než čistě jen fyzikalistický determinismus.

Výhodou částečného kompatibilismu se mi zdá být opora ve zkušenosti. Někdy víme, že jsme se provinili; že jsme měli - a mohli - volit a jednat jinak. Jindy naopak, ačkoli svou morálně dobrou volbu prožíváme jako svobodnou (tj. skutečně svou, řízenou naším vlastním přesvědčením), přece zakoušíme „volní nutnost“: nemůžeme jinak. „Částečný“ či „racionální kompatibilismus“, který hájím a který zahrnuje i Dvořákem zdůrazňovanou „kauzalitu činitele“, nám dovoluje být loajální vůči této variabilitě lidské morální zkušenosti, a být tak svou teorií věrní skutečné povaze našeho morálního života.

\section{Literatura}

Ayer, A. J. (1972): „Freedom and Necessity.“ In Philosophical Essays, A. J. Ayer, Macmillan, London and Basingstoke, 1972, s. 271 -284 .

Cohen, Y. (2016): „Fischer's Deterministic Frankfurt-Style Argument.“ Erkenntnis 82 (1): 121-140. 
Copp, D. (1997): „Defending the Principle of Alternate Possibilities:

Blameworthiness and Moral Responsibility."Noûs 31 (4): 441456.

Driver, J. (2015): „Appraisability, Attributability, and Moral Agency.“

In The Nature of Moral Responsibility. New Essays, eds.

R. Clarke, M. McKenna \& A. M. Smith, Oxford University Press,

New York, 2015, s. 157-174.

Dvořák, P. (2020): Kauzalita činitele. Úvod do analytické diskuse

o svobodě vưle. Togga, Praha.

Fischer, J. M. (2002): „Frankfurt-type Examples and Semi-

Compatibilism." In The Oxford Handbook of Free Will, ed. R.

Kane, Oxford University Press, Oxford, 2002, s. 288-289.

Fischer, J. M. (2006): „Responsibility and Self-Expression.“ In My

Way. Essays on Moral Responsibility, J. M. Fischer, Oxford

University Press, New York, 2006, s. 106-123.

Fischer, J. M. (2010): „The Frankfurt Cases: The Moral of the Stories.“ Philosophical Review 119 (3): 315-336.

Fischer, J. M. (2012): „Conditional Freedom and the Normative

Approach to Moral Responsibility." In Deep Control: Essays on

Free Will and Value, J. M. Fischer, Oxford University Press, New York, 2012, s. 122-143.

Fischer, J. M. \& Ravizza, M. (1991): „Responsibility and Inevitability.“ Ethics 101 (2): 258-278.

Frankfurt, H. G. (1969): „Alternate Possibilities and Moral Responsibility.“ The Journal of Philosophy 66 (23): 829-839.

Frankfurt, H. G. (1998): The Importance of What We Care About. Cambridge University Press, New York.

Frankfurt, H. G. (1999): „On the Necessity of Ideals.“ In Necessity,

Volition, and Love, H. G. Frankfurt, Cambridge University Press,

Cambridge 1999, s. 108-116.

Ginet, C. (1996): „In Defense of the Principle of Alternative

Possibilities: Why I Don't Find Frankfurt's Arguments

Convincing." Philosophical Perspectives 10: 403-417.

Goetz, S. (2005): „Frankfurt-Style Counterexamples and Begging the Question." Midwest Studies in Philosophy 29 (1): 83-105. 
Hume, H. (1975): Enquiry concerning Human Understanding (VIII, 1, § 23). In Enquiries concerning Human Understanding and concerning the Principles of Morals, ed. L. A. Selby-Bigge, $3^{\text {rd, }}$ revize P. H. Nidditch, Clarendon Press, Oxford.

Kane, R. (1985): Free Will and Values. State University of New York Press, Albany.

Kane, R. (1994): Through the Moral Maze. Paragon House, New York.

Kane, R. (1996): The Significance of Free Will. Oxford University Press, New York.

Kane, R. (2005): A Contemporary Introduction to Free Will. Oxford University Press, New York.

Mellema, G. F. (2004): The Expectations of Morality. Rodopi, Amsterdam.

Palmer, D. (2014): „Deterministic Frankfurt cases.“ Synthese 191 (16): $3847-3864$.

Peroutka, D. (2012): „Svoboda vůle podle Tomáše Akvinského.“ In Svoboda od antiky po současnost, ed. A. Havlíček, FF UJEP, Ústí nad Labem, 2012, s. 54-79.

Peroutka, D. (2016): „Poinsot's Compatibilism: An Inspiration for Moral Psychology." Explorations in Late Scholasticism, Filosofický časopis - 2016 (Special Issue, eds P. Dvořák \& T. Machula): 9-22.

Shoemaker, D. (2011): „Attributability, Answerability, and Accountability. Toward a Wider Theory of Moral Responsibility." Ethics 121 (3): 602-632.

Schmitt, J.-C. (2007): Svatý chrt. Guinefort, léčitel dětí ze 13. stol. Academia, Praha.

Schnall, I. M. (2001): „The principle of alternate possibilities and ,ought implies ,can'."Analysis 61 (4): 335-340.

Sripada, Ch. (2016): „Self-expression: a deep self theory of moral responsibility." Philosophical Studies 173 (5): 1203-1232.

Taylor, Ch. (2001): Sources of the Self. The Making of the Modern Identity. Harvard University Press, Cambridge, Massachusetts. 
Tierney, H. (2014): „A Pilgrimage through John Martin Fischer's Deep Control: Essays on Free Will and Value." Criminal Law and Philosophy 10 (1): 179-196.

Widerker, D. (1991): „Frankfurt on ,Ought Implies Can“ and Alternative Possibilities." Analysis 51 (4): 222-224.

Widerker, D. (1995): „Libertarianism and Frankfurt's Attack on the Principle of Alternative Possibilities." The Philosophical Review 104 (2): 247-261.

Widerker, D. \& Goetz, S. (2013): „Fischer against the dilemma defence: the defence prevails." Analysis 73 (2): 283-295.

Wolf, S. (1993): Freedom within Reason. Oxford University Press, New York, Oxford.

\section{Abstract}

\section{Decider's self-determination in compatibilist version}

In reaction to Petr Dvořák's book Agent Causation: Introduction to the Analytic Debate on Free Will I defend a version of compatibilism about free will. Dvořák points out that we do not attribute moral responsibility to an agent whose decision had been predetermined by some causes distinct from him. I propose, however, a kind of "asymmetry thesis". Within the class of predetermined decisions I admit the absence of responsibility in all the cases of morally wrong decisions, but not in all of those we assess as morally good. There are some voluntary decisions, I argue, such that although we are not able, for strong moral reasons, to choose differently, we feel fully free in making our choice or keeping our volition. And even if we have learned, or get to believe, that the volitional necessity in question has not been a result of our past 'libertarian' self-formation, we still hardly could be stopped by such a belief from feeling free in our choice. As philosophers, then, we should opt for respecting the way we actually experience freedom of will.

Key words: free will, self-determination, volitional necessity, compatibilism, libertarianism, Petr Dvořák

Peroutka, D. (2021): „Volitelova sebedeterminace v kompatibilistické verzi.“ Filosofie dnes 13 (1): 47-70. Dostupné z www.filosofiednes.ff.uhk.cz. 